\title{
Genetic Diversity and Structure of Domestic Cavy (Cavia porcellus) Populations from Smallholder Farms in Southern Cameroon
}

\author{
Basengere Ayagirwe ${ }^{1,2,}$, Felix Meutchieye ${ }^{2}$, Appolinaire Djikeng $^{3}$, Robert Skilton ${ }^{4}$, \\ Sarah Osama ${ }^{3}$, Yacouba Manjeli \\ ${ }^{1}$ Department of Animal Production, Faculty of Agriculture and Environmental Studies, Evangelical University in Africa, \\ Bukavu, The Democratic Republic of the Congo. \\ 2 Department of Animal Production, Faculty of Agronomy and Agricultural Sciences, University of Dschang, Cameroon \\ ${ }^{3}$ Biosciences Eastern and Central Africa - International Livestock Research Institute (BecA-ILRI), Nairobi, Kenya \\ ${ }^{4}$ International Centre of Insect Physiology and Ecology (icipe), Nairobi, Kenya \\ *Corresponding author email: ayagirwerodrigue@yahoo.fr
}

\begin{abstract}
Although domestic cavies are widely used in sub-Saharan Africa as a source of meat and income, there are only a few studies of their population structure and genetic relatedness. This seminal study was designed with the main objective to assess the genetic diversity and determine the population structure of cavy populations from Cameroon to guide the development of a cavy improvement program. Sixteen microsatellite markers were used to genotype 109 individuals from five cavy populations (Wouri, Moungo and Nkongsamba in the Littoral region, and Mémé and Fako in the Southwest region of Cameroon). Twelve markers worked in the five populations with a total of 17 alleles identified, with a range of 2.9 to 4.0 alleles per locus. Observed heterozygosity (from 0.022 to 0.277 ) among populations was lower than expected heterozygosity (from 0.42 to 0.54 ). Inbreeding rates between individuals of the populations and between individuals in each population were $59.3 \%$ and $57.2 \%$, respectively, against a moderate differentiation rate of 4.9\%. All the tested loci deviated from Hardy-Weinberg equilibrium, except for locus 3. Genetic distances between populations were small (from 0.008 to 0.277 ), with a high rate of variability among individuals within each population (54.4\%). Three distinct genetic groups were structured. This study has shown that microsatellites are useful for the genetic characterization of cavy populations in Cameroon and that the populations investigated have sufficient genetic diversity that can be used to be deployed as a basis for weight, prolificacy and disease resistance improvement. The genetic of diversity in Southern Cameroon is wide and constitute an opportunity for cavy breeding program.
\end{abstract}

Keywords: guinea pig; microsatellites; genetic diversity; small stock; sub-Saharan Africa

Abstrak. Marmut banyak diternakkan di daerah sub-Sahara Afrika sebagai sumber daging dan pendapatan, namun studi tentang struktur populasi dan hubungan genetik pada marmut masih terbatas. Tujuan penelitian ini adalah untuk mengetahui keragaman genetik dan struktur populasi marmut di Kamerun sebagai panduan dalam pengembangan populasi marmut. Sebanyak 16 penanda mikrosatelit digunakan untuk mengidentifikasi genotip dari 109 individu di lima daerah (Wouri, Moungo dan Nkongsamba di Littoral region, dan Mémé serta Fako di daerah Baratdaya Kamerun). Sebanyak 12 marker dapat digunakan untuk mengidentifikasi 17 allel di lima daerah populasi dengan kisaran 2,9 sampai 4,0 allel per lokus. Heterozigositas yang diamati dalam populasi $(0,022$ sampai 0,277$)$ ternyata lebih rendah daripada yang diharapkan $(0,42$ sampai 0,54$)$. Laju inbreeding antar individu dalam populasi dan antar individu di masing-masing populasi berturut-turut adalah $59,3 \%$ dan $57,2 \%$, dengan laju perbedaan yang sedang yakni $4,9 \%$. Semua loci yang diuji memiliki deviasi dari keseimbangan Hardy-Weinberg, kecuali pada lokus 3. Jarak genetik antar populasi menunjukkan jarak yang kecil $(0,008$ sampai 0,277$)$, dengan variasi yang tinggi antar individu di tiap populasi $(54,4 \%)$. Tiga kelompok genetik dapat diketahui. Studi ini menunjukkan bahwa mikro satelit bermanfaat untuk melakukan karakterisasi genetik pada populasi marmut di Kamerun dan populasi yang dipelajari memiliki keragaman genetik yang memadai sehingga dapat digunakan sebagai basis untuk bobot, prolifikasi dan peningkatan ketahanan penyakit. Keragaman genetik di Baratdaya Kamerun sangat tinggi dan membuka peluang untuk program breeding marmut.

Kata kunci : marmut, mikro satelit, keragaman genetik, skala kecil, sub-Sahara Afrika 


\section{Introduction}

Cavy culture has demonstrated its utility and effectiveness for poverty alleviation in Andean countries in South America (Chauca 1997). However, in numerous sub-Saharan African countries considerable populations of domestic cavies (Cavia porcellus L.) exist that serve for meat consumption, income generation and manure production in mixed crop-livestock systems (Ngou Ngoupayou et al. 1995; Kouakou et al. 2011; Matthiesen et al. 2011; Niba et al. 2012; Maass et al. 2014; Yiva et al. 2014).

It is not known, where, when and how often cavies have been introduced in Cameroon. However, it is speculated that cavy husbandry has been known at least since 1968 (Yiva et al. 2014). Except for two development projects (Hardouin 1995; Nuwanyakpa et al. 1997), there was no promotion of the animal, but farmers took up cavy culture by themselves across the country. To increase productivity, one project introduced descendants from a large body size line developed in Peru to Northwest Cameroon in 1996 (Nuwanyakpa et al. 1997). Niba et al. (2012), however, presume that this breed has possibly been assimilated in the local gene pool.

Since 2001, the use of cavies has been promoted by the Ministry of Livestock, Fisheries and Animal Industries in Cameroon as part of short-cycle livestock species targeted to meet the national demand for animal proteins (Niba et al. 2012). Domestic cavies are widely reared and consumed in Cameroon (Manjeli et al. 1998; Ngou Ngoupayou et al. 1995; Niba et al. 2012; Yiva et al. 2014), contributing to income generation in poor households since their rearing does not require significant capital (Lammers et al. 2009; Niba et al. 2012).

Although cavies appear morphologically similar considering their coat color pattern, genetically they might represent different populations. Largest cavy populations are known to exist in Cameroon with high phenotypic viabilities (Ayagirwe et al. 2015); this have been studied by molecular markers (Poutougnigni et al. 2015; Wikondi et al. 2015) in some populations and did not cover the southern part of the country. Ayagirwe (2014) suggested that the main ecotypes in southern Cameroon are from Wouri, Moungo and Nkongsamba in the Littoral (coastal) region, and Fako and Mémé in the Southwest region.

Because of their polymorphism and their homogeneous distribution in the genome, molecular markers are powerful tools for describing animal populations (Mohamed et al. 2010). However, the use of molecular markers in domestic cavy to reveal diversity patterns is recent and limited to few populations from South America (Spotorno et al. 2004; Kanitz et al. 2009; Burgos et al. 2011) and, only lately, from Africa for the Côte d'Ivoire cavy population (Kouakou et al. 2015). It is, therefore, necessary to extend these studies to populations in other African countries for better understanding cavy genetic diversity to help to guide cavy breeding in sub-Saharan Africa.

\section{Materials and Methods}

\section{Study area}

This study was conducted in Wouri, Moungo and Nkongsamba in the Littoral (coastal) region, and Mémé and Fako in the Southwest region of Cameroon. The Littoral and Southwest administrative regions of Cameroon, a unimodal agro-ecological zone, are located between $2^{\circ} 6^{\prime}$ and $6^{\circ} 12^{\prime}$ north, $8^{\circ} 48^{\prime}$ and $10^{\circ} 30^{\prime}$ east, with elevations from 0 to $4095 \mathrm{~m}$ a.s.l. This region occupies an area of 4.5 million ha, of which 282,000 ha $(6.3 \%)$ are cultivated with agricultural crops. The climate is typically equatorial: with an average annual rainfall of 2500 to $4000 \mathrm{~mm}$, air humidity of 85 to $90 \%$, and mean monthly temperature between 22 and $29^{\circ} \mathrm{C}$ (FAO 2008).

\section{Sampling and collection of blood}

A total of 109 blood samples were collected from adult cavies of about four months of age. 


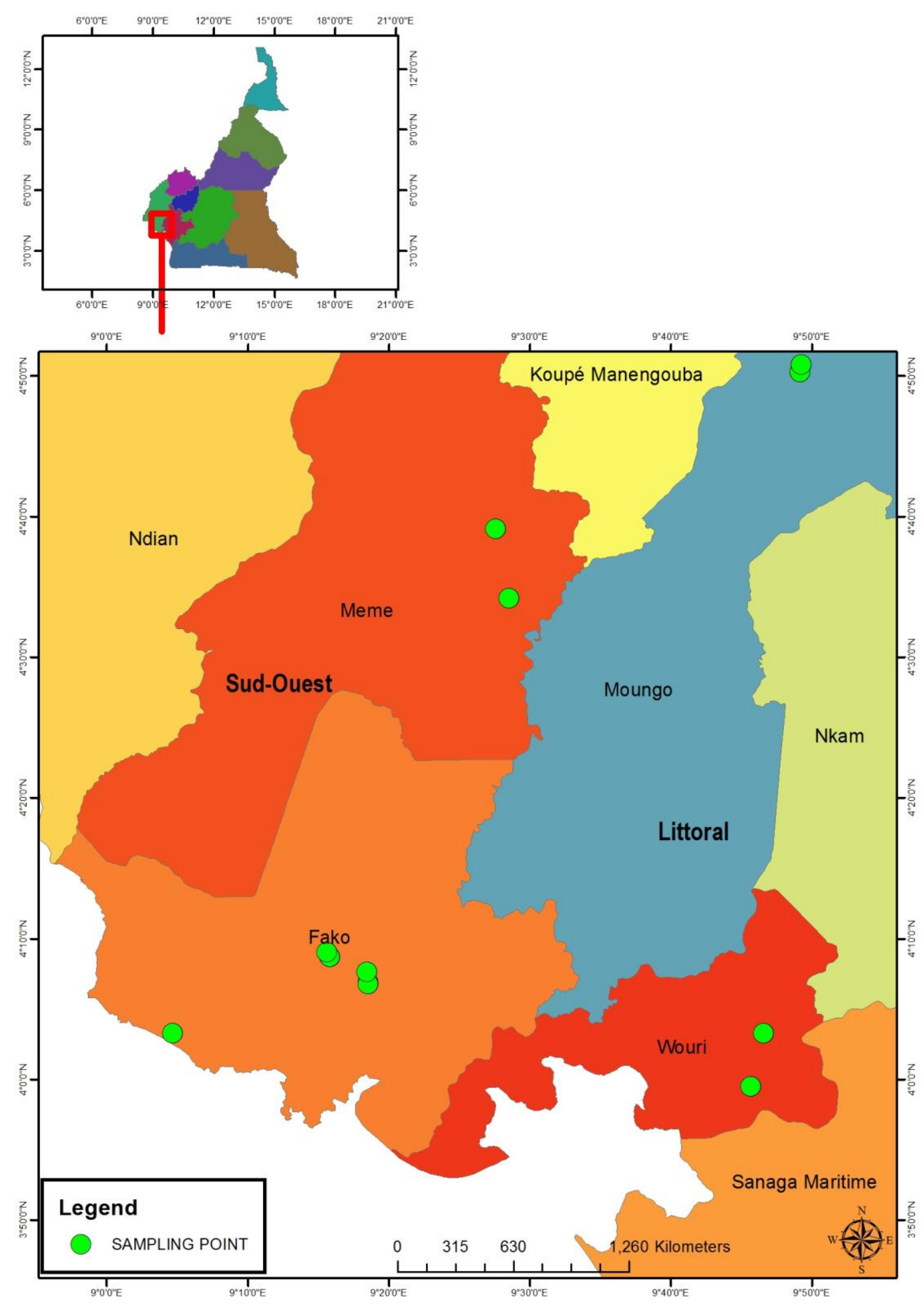

Figure 1. Household surveyed in the different regions of Southern Cameroon

To select within the five populations, the snowball method was used (Salganik and Heckathorn 2004), because of lack of information available on cavy keepers. Identified cavy-keeping household helped in identifying others. Usually, one animal was sampled if the cavy population size per household was below 30 animals, except if conspicuously unusual phenotypes were encountered. The animals were selected with 
the objective of obtaining the largest variability of phenotypic characteristics within each population following the method of Kosaki and Juo (1989).

Blood samples were collected from adult animals by pricking the disinfected ear vein with a 22 gauge needle. Blood was spotted onto Whatman FTA Classic Cards (Cambridge Bioscience, United Kingdom), according to the manufacturer's instructions and air dried.

\section{DNA extraction}

For the total DNA extraction, twenty $1.5 \mathrm{~mm}$ punches of the FTA Card blood spots were added to $1 \mathrm{ml}$ of $100 \mathrm{mM}$ Tris $\mathrm{pH} 8,0.1 \%$ SDS and the supernatant was removed after $30 \mathrm{~min}$ of agitation. A total volume of five hundred $\mu \mathrm{l}$ of $1.5 \mathrm{M}$ guanidinium thiocyanate was added, and after $10 \mathrm{~min}$ of vortexing all the supernatant was removed. The discs were then washed three times with $500 \mu$ of triple distilled water, with $10 \mathrm{~min}$ of centrifugation between each wash. Then, $50 \mu$ l triple distilled water was added to the discs and the mixture placed in a water bath and heated to $90^{\circ} \mathrm{C}$ for $20 \mathrm{~min}$. After $30 \mathrm{~min}$ of cooling, DNA was recovered by centrifugation and stored at $20^{\circ} \mathrm{C}$.

\section{PCR amplification of microsatellites}

Sixteen microsatellite markers previously reported for the species Cavia porcellus were evaluated (Spotorno et al. 2004; Kanitz et al. 2009; Burgos et al. 2011). PCR amplification was carried out in C1000 thermal cycler (Bio-Rad). The final volume of the reaction was $10 \mu \mathrm{l}$, containing $2 \mu \mathrm{l}$ of $40 \mathrm{ng} / \mu \mathrm{l}$ template DNA, 1x DreamTaq buffer containing $2 \mathrm{mM} \mathrm{MgCl} 2$ (Fermentas), $200 \mu \mathrm{M}$ of each dNTP, and $0.4 \mathrm{U}$ of DreamTaq DNA polymerase (Fermentas). PCR conditions were: $95^{\circ} \mathrm{C}$ for $3 \mathrm{~min}$, followed by 35 cycles of $30 \mathrm{sec}$ at $94^{\circ} \mathrm{C}$ for template denaturation, $30 \mathrm{sec}$ at $60^{\circ} \mathrm{C}$ primer annealing and $60 \mathrm{sec}$ at $72^{\circ} \mathrm{C}$ for primer extension, followed a final primer extension step at $72{ }^{\circ} \mathrm{C}$ for $20 \mathrm{~min}$. PCR products were analyzed using $1.5 \%$ agarose gel electrophoresis.

\section{Data analysis}

The data was captured using the GenScan ${ }^{\circledR}$ collection software (Applied Biosystems) and the allelic data analyzed using the GeneMapper ${ }^{\circledR}$ software version 4.1 (Applied biosystems). A total 103 data points were achieved out of the expected 109 data point giving an overall success rate of $94.5 \%$.The data was compiled into a spreadsheet as a standard GeneMapper output file and used in subsequent analysis.

Allele scoring was done using GeneMapper software V4.1 (Timothy 2009). The observed heterozygosity ( $\mathrm{Ho}$ ) and unbiased expected heterozygosity $(\mathrm{He})$ were calculated under the assumption of Hardy-Weinberg equilibrium with allele frequencies observed according to Nei (1978); the average number of alleles ( $\mathrm{Na}$ ) (Crow and Kimura 1970) were calculated using Arlequin software V3.1 (Excoffier et al. 2005). The test of Hardy-Weinberg equilibrium was conducted with Power Marker software V3.25 (Liu and Muse 2005).

Admixture were investigated. For grouping individuals into a $K^{\text {th }}$ number of population, Bayesian probabilistic group assignment was done using STRUCTURE software (Pritchard et al. 2000). $K$ values analyzed ranged from to $1-5$ and each one was simulated five times. Correlated allele frequency with mixing model was used for runs with 100,000 iteration following a 10,000 burn-in period. The Delta K method described by Evanno et al. (2005) was applied for inferring optimal k-values.

\section{Results and Discussion}

\section{Indices of genetic diversity within and among populations}

Mean number of alleles observed varied from $2.909 \pm 1.221$ for the population of Nkongsamba to $4.0 \pm 1.549$ for the population of Wouri, with an overall average of $3.455 \pm$ 1.809 (Table 1). The lower number of alleles 
found for the population of Nkongsamba may partly reflect geographical differences observed between different areas, but also the smaller sample size compared to the other populations.

The observed and expected heterozygosity rates were calculated for each population under Hardy-Weinberg equilibrium. To estimate the importance of genetic polymorphism, observed and expected heterozygosity rates were compared. The expected rates were higher than those observed for all populations reflecting a heterozygote deficiency. The highest rate was 0.277 in the population of Wouri. These results were consistent with the rates of inbreeding observed for all loci studied, which were very high IN all studied populations (Table 1 ).

Table 2 shows the results of the HardyWeinberg equilibrium test for all loci studied and for all populations. The population of Nkongsamba presented a high balance compared to other populations. Outside the locus cavy 3 , which was in equilibrium in all populations, all other deviated from that equilibrium. However, considering each subpopulation, there were also loci in balance with the Hardy-Weinberg equilibrium. This was the case of loci cavy 2, 3, 8, 11 for Fako, cavy loci 2, 3, 8 for Wouri; cavy 3, 6, 8, 10 and 14 for Mémé; and loci cavy 3 and 7 for Moungo, whereas in the population of Nkongsamba, only loci cavy 2, 7 and 8 showed a deviation from the Hardy-Weinberg equilibrium. The equilibrium observed for locus cavy 3 confirmed the absence of inbreeding at this locus, while the other loci showed a high rate of inbreeding and violations of equilibrium conditions.

Molecular variance assessed in the total study population is summarized in Table 3. A high variability was observed among individuals within each population (54.4\%) and between individuals of the total population (40.6\%), leaving only a small percentage $(4.9 \%)$ of variation among populations.

Among the five populations studied, those from Nkongsamba and Moungo had the greatest genetic distance but also the lowest genetic identity, respectively, 0.227 and 0.758 (Table 4). Populations from Mémé and Fako, both from Southwest Region, on the other hand, were those closest as having the greatest genetic identity and the lowest genetic distance (0.992 and 0.008, respectively). Low genetic distances observed among populations show that they were close and probably had a common history.

\section{Structure and phylogenetic relationship between populations}

The number of genetic populations was equal to $K=3$ (Figure 1), the peak obtained following Evanno et al. (2005). Thus, the overall study population was considered to be composed of three distinct genetic types. Populations from Wouri and Moungo were composed of one dominant subpopulation (green) despite the presence of introgression, whereas other populations consisted of two subpopulations. Observed introgression implies that much of the distribution of individuals is done regardless of their geographical origin and, probably, uncontrolled crosses take place between existing genetic types.

\section{Discussion}

This study reports, a study on genetic diversity and population structure of domestic cavies from Cameroon at molecular level. Seventeen alleles were observed in the total population with an average of 3.5 alleles per locus in five populations studied. The lowest number of alleles where observed in Nkongsamba ecotype (2.909) while Wouri had the greatest number (4.00). Poutougnigni et al. (2015) and Wikondji et al. (2015) obtained respectively 5.1 and 5.9 alleles per locus in population from forest and highland regions in Cameroun. Compared to Southwest region, number of alleles per ecotype from littoral region seems to be more variable. The overall number of alleles observed in this study was lower than that determined by Kouakou et al. 
Table 1. Number of alleles and heterozygosity rate in five cavy populations studied from Littoral and Southwest Regions of Cameroon ( $N=109)$

\begin{tabular}{|c|c|c|c|c|c|c|c|c|c|c|c|c|c|c|c|c|}
\hline \multirow{2}{*}{ Locus } & \multicolumn{3}{|c|}{ Wouri $(N=21)$} & \multicolumn{3}{|c|}{ Nkongsamba $(\mathrm{N}=15)$} & \multicolumn{3}{|c|}{ Moungo $(N=30)$} & \multicolumn{3}{|c|}{ Mémé ( $N=22)$} & \multicolumn{4}{|c|}{ Fako $(\mathrm{N}=21)$} \\
\hline & $\mathrm{Na}$ & Ho & $\mathrm{He}$ & $\mathrm{Na}$ & Ho & $\mathrm{He}$ & $\mathrm{Na}$ & Ho & $\mathrm{He}$ & $\mathrm{Na}$ & Ho & $\mathrm{He}$ & $\mathrm{Na}$ & Ho & $\mathrm{He}$ & $\mathrm{F}$ \\
\hline Cavy2 & na & na & na & 3 & 0.083 & 0.163 & 2 & 0.037 & 0.107 & 2 & 0.000 & 0.138 & 2 & 0.111 & 0.203 & 0.72 \\
\hline Cavy3 & 2 & 0.125 & 0.121 & 2 & 0.071 & 0.071 & na & na & na & na & na & na & na & na & na & -0.01 \\
\hline Cavy6 & 8 & 0.600 & 0.790 & 5 & 0.333 & 0.641 & 6 & 0.542 & 0.676 & 6 & 0.583 & 0.822 & 8 & 0.615 & 0.794 & 0.31 \\
\hline Cavy7 & 3 & 0.000 & 0.514 & 3 & 0.111 & 0.582 & 3 & 0.333 & 0.591 & 3 & 0.067 & 0.545 & 4 & 0.118 & 0.364 & 0.86 \\
\hline Cavy8 & 4 & 0.286 & 0.261 & 2 & 0.000 & 0.192 & 3 & 0.240 & 0.389 & 3 & 0.200 & 0.191 & 2 & 0.167 & 0.157 & 0.29 \\
\hline Cavy9 & 3 & 0.235 & 0.670 & 2 & 0.500 & 0.500 & 3 & 0.240 & 0.493 & 3 & 0.071 & 0.505 & 3 & 0.111 & 0.565 & 0.68 \\
\hline Cavy10 & 4 & 0.368 & 0.596 & 2 & 0.125 & 0.125 & 4 & 0.150 & 0.550 & 3 & 0.250 & 0.540 & 2 & 0.125 & 0.484 & 0.60 \\
\hline Cavy11 & 4 & 0.267 & 0.736 & 2 & 0.000 & 0.667 & 4 & 0.125 & 0.442 & 4 & 0.167 & 0.712 & 3 & 0.143 & 0.385 & 0.72 \\
\hline Cavy12 & 5 & 0.158 & 0.589 & 4 & 0.182 & 0.249 & 4 & 0.000 & 0.550 & 3 & 0.000 & 0.304 & 2 & 0.000 & 0.129 & 0.86 \\
\hline Cavy14 & 4 & 0.150 & 0.558 & 5 & 0.444 & 0.760 & 3 & 0.059 & 0.508 & 3 & 0.167 & 0.591 & 3 & 0.083 & 0.475 & 0.74 \\
\hline Cavy15 & 3 & 0.286 & 0.577 & 2 & 0.000 & 0.667 & 4 & 0.138 & 0.564 & 4 & 0.313 & 0.683 & 5 & 0.263 & 0.690 & 0.65 \\
\hline Cavy16 & 4 & 0.571 & 0.632 & na & na & na & 3 & 0.480 & 0.598 & 4 & 0.600 & 0.701 & 4 & 0.188 & 0.675 & 0.33 \\
\hline Mean & 4.000 & 0.277 & 0.549 & 2.909 & 0.168 & 0.420 & 3.545 & 0.213 & 0.497 & 3.455 & 0.022 & 0.521 & 3.455 & 0.175 & 0.447 & 0.60 \\
\hline$S D$ & 1.549 & 0.182 & 0.197 & 1.221 & 0.179 & 0.26 & 1.036 & 0.177 & 0.151 & 1.036 & 0.208 & 0.223 & 1.809 & 0.16 & 0.224 & 0.221 \\
\hline
\end{tabular}

$\mathrm{N}$ : sample size; Na: number of alleles; Ho: observed heterozygosity; He: expected heterozygosity; F: Inbreeding; na: not available. Wouri, Moungo and Nkongsamba are in the Littoral region, and Mémé and Fako are in the Southwest Region of Cameroon. 
Table 2. Test of significance of the Hardy-Weinberg equilibrium per locus and cavy population from Littoral and Southwest Regions of Cameroon ( $N=109)$

\begin{tabular}{lcccccc}
\hline Locus & Littoral Region & & & & Southwest Region & \\
\cline { 2 - 4 } \cline { 6 - 7 } & Wouri & Nkongsamba & Moungo & & Mémé & Fako \\
\hline Cavy2 & $\mathrm{ns}$ & $* * *$ & $* * *$ & & $* * *$ & $\mathrm{~ns}$ \\
Cavy3 & $\mathrm{ns}$ & $\mathrm{ns}$ & $\mathrm{ns}$ & & $\mathrm{ns}$ & $\mathrm{ns}$ \\
Cavy6 & $*$ & $\mathrm{~ns}$ & $* *$ & & $\mathrm{~ns}$ & $*$ \\
Cavy7 & $* * *$ & $* *$ & $\mathrm{~ns}$ & & $* *$ & $* *$ \\
Cavy8 & $\mathrm{ns}$ & $* * *$ & $* * *$ & & $\mathrm{~ns}$ & $\mathrm{~ns}$ \\
Cavy9 & $* *$ & $\mathrm{~ns}$ & $* * *$ & & $* * *$ & $* * *$ \\
Cavy10 & $*$ & $\mathrm{~ns}$ & $* * *$ & & $\mathrm{~ns}$ & $* *$ \\
Cavy11 & $* *$ & $\mathrm{~ns}$ & $* * *$ & & $*$ & $\mathrm{~ns}$ \\
Cavy12 & $* * *$ & $\mathrm{~ns}$ & $* * *$ & & $* * *$ & $* * *$ \\
Cavy14 & $* * *$ & $\mathrm{~ns}$ & $* * *$ & & $\mathrm{~ns}$ & $* * *$ \\
Cavy15 & $* *$ & $\mathrm{~ns}$ & $* * *$ & & $* * *$ & $* * *$ \\
Cavy16 & $* * *$ & $\mathrm{~ns}$ & $* * *$ & & $* *$ & $* * *$ \\
\hline
\end{tabular}

ns, not significant; ${ }^{*}, * *$, and ${ }^{* * *}$, significant at $\mathrm{p} \leq 0.05, \mathrm{p} \leq 0.01$ and $\mathrm{p} \leq 0.001$, respectively

Table 3. Analysis of molecular variance in the total cavy population studied from Littoral and Southwest Regions of Cameroon

\begin{tabular}{llll}
\hline Source of variation & Sum squares & $\begin{array}{l}\text { Variance } \\
\text { components }\end{array}$ & $\begin{array}{l}\text { Percentage } \\
\text { variation }\end{array}$ \\
\hline Among populations & 33.41 & 0.14 & 4.92 \\
Among individuals within populations & 295.53 & 1.61 & 54.41 \\
Within individuals & 91,0 & 1.20 & 40.66 \\
\hline Total & 419.95 & 2.96 & \\
\hline
\end{tabular}

Table 4. Unbiased genetic distance and identity of Nei between different cavy populations from Littoral and Southwest Regions of Cameroon

\begin{tabular}{llllll}
\hline & Populations & & & \\
\cline { 2 - 6 } & Wouri & Nkongsamba & Moungo & Mémé & Fako \\
\hline Wouri & & $\mathbf{0 . 2 2 6}$ & $\mathbf{0 . 1 0 1}$ & $\mathbf{0 . 0 3 1}$ & $\mathbf{0 . 0 4 9}$ \\
Nkongsamba & 0.798 & & $\mathbf{0 . 2 7 7}$ & $\mathbf{0 . 1 7 4}$ & $\mathbf{0 . 2 2 0}$ \\
Moungo & 0.904 & 0.758 & & $\mathbf{0 . 0 5 3}$ & $\mathbf{0 . 1 0 0}$ \\
Mémé & 0.969 & 0.840 & 0.949 & & $\mathbf{0 . 0 0 8}$ \\
Fako & 0.952 & 0.802 & 0.905 & 0.992 & \\
\hline
\end{tabular}

Unbiased genetic distance are shown above the diagonal (indicated in bold) and identity of Nei is shown below the diagonal $(\mathrm{N}=109)$ 


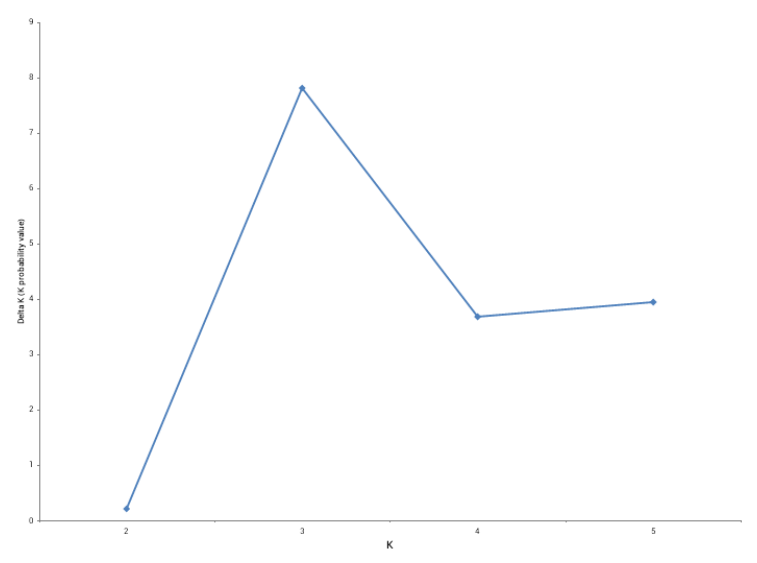

Figure 2. The uppermost hierarchical level of genetic partitioning among the overall cavy population from Littoral and Southwest Regions of Cameroon $(N=109)$ assessed according to Evanno et al. (2005)

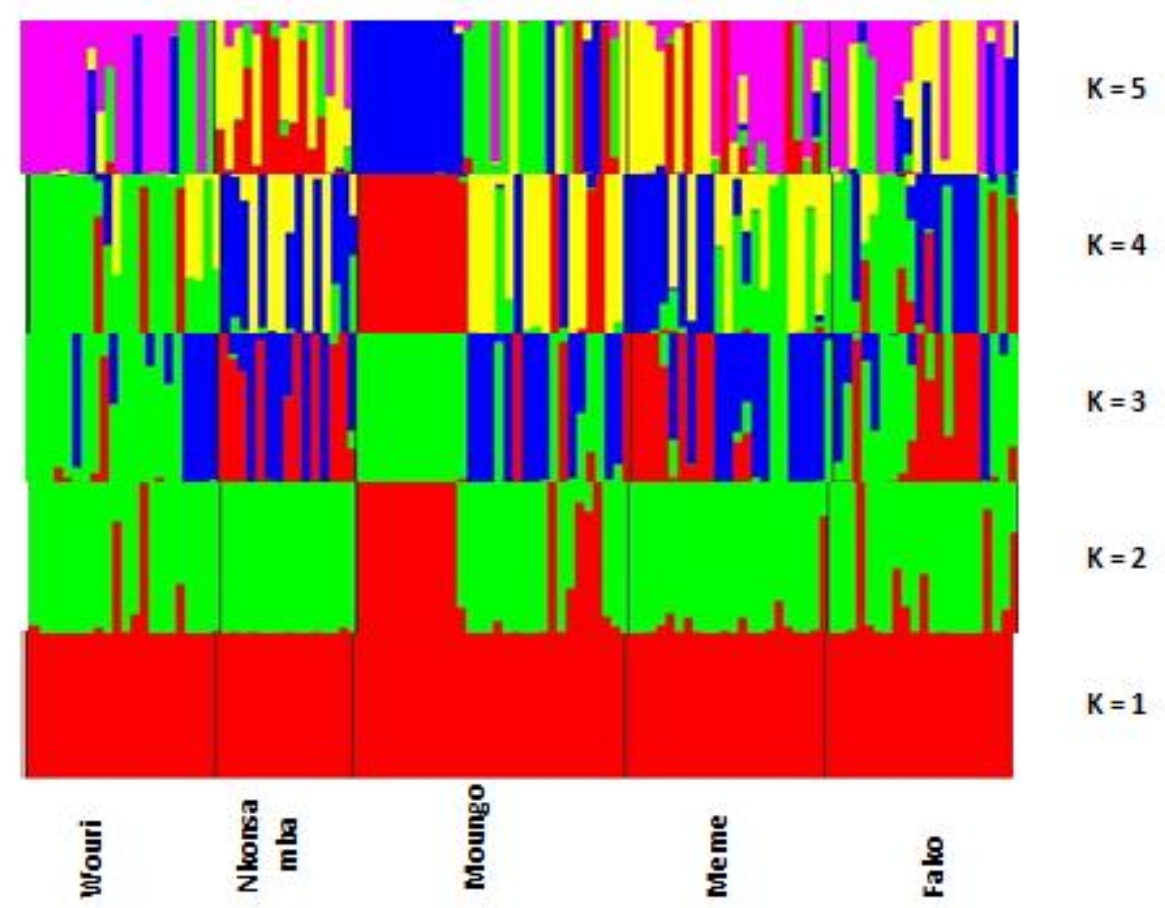

Figure 3. Genetic structure of the total cavy population from Littoral and Southwest Regions of Cameroon ( $\mathrm{N}=109$ ). The overall population is partitioned into $\mathrm{K}$ groups corresponding to the number of colors; black vertical lines separate the different populations studied.

(2015) who obtained on average $5.98 \pm 0.37$ alleles from Cote d'Ivoire cavy populations using the same markers; however, these authors sampled from large parts of the country, while this study focused on a much narrower geographic area in Cameroon. BurgosPaz et al. (2011) in three lines of domestic cavy from Colombia/South America, recorded on average 6.8 alleles per locus with a total of 34 alleles, when using 5 microsatellites; however, 
this number is close to that obtained in the tame line (4.8 alleles). Unsurprisingly, Kanitz et al. (2009) found an even higher average number of alleles of 8.5 and 6.3, respectively, for the wild species Cavia magna and Cavia aperea. The relatively low number of alleles observed in the current study could be due to the small sample size, assuming that an increase of the sampled population would result in an increase of the probability of finding new alleles (Foulley et al. 2006). In addition, the low number of alleles observed could also be related to mutations, deletions and a high level of inbreeding in the population. Finally, it is to be expected that only a fraction of genetic diversity available in South American domestic cavies has been introduced to Africa, whenever and how often this introduction has taken place.

In the whole studied populations, the expected heterozygosity was high than the observed heterozygosity. The same observation have been done by Wikondi et al. (2015) and Poutougnigni et al. (2015) in highland and forest cavy populations from Cameroon. Populations from Southwest region had the high deviation from expected heterozygosity ( 0.499 for Mémé and 0.302 for Fako) compared to those form littoral. Both the expected and observed heterozygosity values obtained by Kouakou et al. (2015), respectively, $0.619 \pm 0.03$ and $0.528 \pm 0.04$ for expected and observed heterozygosity are higher than those reported in this study. The same conclusions are found considering the results from Kanitz et al. (2009) studying two wild cavies; Cavia magna and Cavia aperea (0.681 and 0.648, and 0.656 and 0.573 , respectively). The high rate of inbreeding (0.60) observed in the studied populations could help explain the low rates of observed and expected heterozygosity. On the other hand, the largest deviation from expected heterozygosity ( 0.499 across all loci for Mémé) was lower than that reported by Burgos-Paz et al. (2011).
Except for locus cavy 3, all studied loci deviated from Hardy-Weinberg equilibrium in the general population. These results differ from those obtained by Kanitz et al. (2009), who observe a balance for all markers in $C$. aperea, but deviation in the loci cavy1, 5 and 10 in C. magna. Burgos-Paz et al. (2011) record a deviation from Hardy-Weinberg equilibrium at 4 out of 5 loci in three lines of domestic cavy in Colombia (native cavy, improved and tame cavy). These results show that, as long as there is restricted flock size, Hardy-Weinberg equilibrium is deviated in some loci.

The deviation from the equilibrium in this study can be explained by the fact that in Cameroon, the average size of a cavy population is 18 per household (Ngou Ngoupayou et al. 1995; Yiva et al. 2014), and this small flock size cannot lead to random mating. In addition, there is often exchange of animals among farmers within a region and even among regions.

The high rate of molecular variance observed between individuals from different populations and between individuals of the same population have been already reported as well by Wikondi et al. (2015) and Poutougnigni et al. (2015) in highland and forest cavy populations from Cameroon and would suggest there are opportunities for intra-population selection before crossing individuals from the different populations for possible genetic improvement of the species in Cameroon. Similar results have been found by Kouakou et al. (2015) who also recorded a small molecular variation among populations (2.6\%), while within populations and individuals it was intermediate (22.0\%) and large (75.4\%) respectively. This could be related to low exchange of animals within Côte d'Ivoire compared to Cameroon.

The five populations in this study were structured into three distinct genetic groups. Evolutionary theory of populations can help explain these groups. According to Mohamed et 
al. (2010), the genetic constitution of a population has a possibility of variation over time, and there are forces that determine genetic variations of populations. The result of these evolutionary forces is to vary the rate of heterozygosity of the population compared to the Hardy-Weinberg equilibrium. In addition, two populations of the same species may be subject to different evolutionary factors, resulting in genetic divergence from one another over time, which can produce an effect on both allele frequencies and the relationship between observed and expected heterozygosity. Chauca (1997) noted that, in general, the population of cavy has preserved significant genetic and phenotypic variability.

A low level of genetic structure as observed in this study and a high rate of inbreeding has been reported from several production systems. This could be attributed to nonrandom mating and selection (e.g., Granevitze et al. 2007 for chicken; Kumar et al. 2006 for buffalo; Serrano et al. 2009 for goats; Wu et al. 2009 for ducks). As a short-cycle small livestock species, cavy is not different when considering its rapid growth, high reproductive rate and the traditional farming system in Cameroon. The species is susceptible to very high inbreeding rates as found in this study.

\section{Conclusion}

The results of this study show that existing microsatellites developed for cavy populations in South America are useful tools for the genetic characterization of cavy populations in sub-Saharan Africa. They indicate that the studied populations from southern Cameroon have a satisfactory genetic diversity that can be used as a basis for conservation of and selection from this small livestock species to improve productivity. Future studies should expand to include cavy populations from northern and northwestern regions of Cameroon as well as those from other African countries. This may help not only to identify useful pockets of less related genetic diversity for improvement but also clarify the possible evolution of domestic cavy on the African continent.

\section{Acknowledgements}

We acknowledge the Biosciences eastern and central Africa - International Livestock Research Institute (BecA-ILRI) Hub, for manifold support to this project which was graciously supported through the Australian Department of Foreign Affairs and Trade (DFAT) through the Commonwealth Scientific and Industrial Research Organization (CSIRO) and the BecAILRI Hub [Project No. CSI002-GUI]. Rodrigue Ayagirwe was further supported by the BecAILRI Hub through the Africa Biosciences Challenge Fund (ABCF) program. The ABCF Program is funded by the Australian Department for Foreign Affairs and Trade (DFAT) through the BecA-CSIRO partnership; the Syngenta Foundation for Sustainable Agriculture (SFSA); the Bill \& Melinda Gates Foundation (BMGF); the UK Department for International Development (DFID) and; the Swedish International Development Cooperation Agency (Sida)."We thank cavy owners in southern Cameroon for providing unreserved access to their animals for sampling. Dr. B. L. Maass is acknowledged for support and constructive comments on an earlier manuscript.

\section{References}

Ayagirwe, RBB, Meutchieye, F, Wikondi, J, Poutougnigni, YM, Niba, AT and Manjeli, Y. 2015. Variabilité phénotypique dans les populations de cobayes domestiques (Cavia porcellus) du Cameroun, Bull. Anim. Hlth. Prod. Afr. AnGR Special Edition, 43 - 50

Ayagirwe, RBB, 2014. Diversité génétique et structure des populations de cobayes dans la zone agro-écologique monomodale du Sud Cameroun. MSc thesis, University of Dschang, Dschang, Cameroon. 
Burgos-Paz W, Cerón-Muñoz M, Solarte-Portilla C. 2011. Genetic diversity and population structure of the Guinea pig (Cavia porcellus, Rodentia, caviidae) in Colombia, Gen. Mol. Biol. 34, 711718.

Chauca, Z L. 1997. Producción de cuyes (Cavia porcellus). Food and Agriculture Organization (FAO), Rome, Italy. Website last accessed 2015 Aug.

11: http://www.fao.org/docrep/w6562s/w6562s00.h tm.

Crow, JF, Kimura, M. 1970. An introduction to population genetics theory. Harper and Row, New York, Evanston and London.

Evanno, G, Regnaut, S, Goudet, J. 2005. Detecting the number of clusters of individuals using the software STRUCTURE: a simulation study. Mol. Ecol. 14, 2611-2620.

Excoffier, L, Laval, G, Schneider, S. 2005. Arlequin 3.0: An integrated software package for population genetics data analysis. Evol. Bioinf. Online 1, 47-50. Website last accessed 2015 Aug. 11: http://cmpg.unibe.ch/software/arlequin3.

FAO. 2008. Rapport national sur l'état des ressources phytogénétiques pour l'alimentation et I'agriculture: Cameroun. Institute de Recherche Agricole pour le Developpement (IRAD), Yaoundé, Cameroon. Website last accessed 2015 Aug.

11: http://www.fao.org/docrep/013/i1500e/Camero un.pdf.

Felsenstein, J. 2005. Phylip (Phylogeny Inference Package) version 3.6. Department of Genome Sciences, University of Washington, Seattle, USA. Website last accessed 2015 Aug. 11: http://evolution.genetics.washington.edu/phylip. html.

Foulley, JL, Ollivier, L. 2006. Diversité génétique et richesse allélique: concepts et application à des races bovines. Renc. Rech. Ruminants 13, $227-$ 230.

Granevitze, Z, Hillel, J, Chen, GH, Cuc, NT, Feldman, M, Eding, H, Weigend, S. 2007. Genetic diversity within chicken populations from different continents and management histories. Anim. Genet. 38, 576-583.

Hardouin, J. 1995. Minilivestock: from gathering to controlled production. Biodiv. Conserv. 4, 220232.

Hubisz, MJ, Falush, D, Stephens, M and Pritchard, JK. 2009. Inferring weak population structure with the assistance of sample group information. Mol. Ecol. Resour. 9, 1322-1332.

Kanitz, R, Trillmich, F, Bonatto, SL. 2009. Characterization of new microsatellite loci for the South-American rodents Cavia aperea and Cavia magna. Conserv. Genet. Resour. 1, 47-50.
Kosaki, T, Juo, A SR. 1989. Multivariate approach to grouping soils in small fields. 1. Extraction of factors causing soil variation by Principal Component Analysis. Soil Sci. Plant Nut. 35, 469477.

Kouakou, NDV, Speybroeck, N, Assidjo, EN, Grongnet, JF, Thys, E. 2011. Typifying guinea pig (Cavia porcellus) farmers in urban and peri-urban areas in central and southern Côte d'Ivoire. Outlook on Agric. 40, 323-328.

Kouakou, KP, Skilton, R, Djikeng, A, Fantodji, A, Gourene, B, Aoussi, SC. 2015. Genetic diversity and population structure of cavy (Cavia porcellus L) in three agro ecological zones of Côte d'Ivoire. IJAAR. 6, 27-35.

Kumar, S, Gupta, J, Kumar, N, Dikshit, K, Navani, N, Jain, P, Nagarajan, M. 2006. Genetic variation and relationships among eight Indian riverine buffalo breeds. Mol. Ecol. 15, 593-600.

Lammers, PJ, Carlson, SL, Zdorkowski, GA, Honeyman, MS. 2009. Reducing food insecurity in developing countries through meat production: the potential of the guinea pig (Cavia porcellus). Renew. Agric. Food Syst. 24, 155-162.

Liu, K, Muse, SV. 2005. Power Marker: Integrates analysis environment for genetic marker data. Bioinf. 21, 2128-2129.

Manjeli, Y, Tchoumboue, J, Njwe, RM, Teguia, A. 1998. Guinea-pig productivity under traditional management. Trop. Anim. Health Prod. 30, 115122.

Matthiesen, T, Nyamete, F, Msuya, JM, Maass, BL. 2011. Importance of guinea pig husbandry for the livelihood of rural people in Tanzania: a case study in Iringa Region. Presented at Development at the Margin, Tropentag, 5-7 Oct. 2011, University of Bonn, Germany. Book of Abstracts, p. 342. Website accessed 2015 Aug 10: http://www.tropentag.de/2011/abstracts/links/ Matthiesen IIDdf2DY.pdf.

Mohamed, OA, Farhat, BS, Bedhiaf, S, Djemali, M. 2010. Analyse moléculaire de la diversité génétique des dromadaires (Camelus dromedarius) en Tunisie. Biotechnol. Agron. Soc. Environ. 14, 399-408.

Nei, M. 1978. Estimation of average heterozygosity and genetic distance from a small number of individuals. Genetics 89, 583-590.

Ngou-Ngoupayou, JD, Kouonmenioc, J, Fotso, T JM, Cicogna, M, Castroville, C, Rigoni, M, Hardouin, J. 1995. Possibilités de développement de l'élevage du cobaye en Afrique subsaharienne: le cas du Cameroun. World Animal Review (FAO/AGA) 83, 21-28.

Niba, AT, Meutchieye, F, Fon, D, Laisin, AG, Taboh, $H$, Njakoi, H, Bela, TA, Maass, BL, Djikeng, A, Manjeli, Y. 2012. Current situation of cavy 
production in Cameroon: Challenges and opportunities. $L R R D$. 24. Available from: http://www.Irrd.org/Irrd24/11/niba24194.htm (online 6 Nov. 2012).

Poutougnigni, MY, Meutchieye, F, Ayagirwe, RBB and Manjeli, Y. 2015. Caractérisation biomoléculaire et structure de la population des cobayes de la zone agro-écologique à pluviométrie bimodale du Cameroun, Bull. Anim. Hlth. Prod. Afr. AnGR Special Edition, 321 - 335.

Salganik, MJ, Heckathorn, DD. 2004. Sampling and estimation in hidden populations using respondent-driven sampling. Sociol. Meth. 34, 193-239.

Serrano, $M$, Calvo, JH, Martínez, M, MarcosCarcavilla, A, Cuevas, J, González, C, Jurado, JJ, Díez de Tejada, P. 2009. Microsatellite based genetic diversity and population structure of the endangered Spanish Guadarrama goat breed. BMC Genetics 10, 6.

Solarte-Portilla, C, Cárdenas-Henao, H, RoseroGalindo, C, Burgos-Paz, W. 2007. Caracterización molecular de tres líneas de Cavia porcellus mediante la aplicación de AFLP. Rev. Col. Cien. Pec. 20, 49-58.
Spotorno, AE, Valladares, JP, Marín, JC, Zeballos, H. 2004. Molecular diversity among domestic guinea-pigs (Cavia porcellus) and their close phylogenetic relationship with the Andean wild species Cavia tschudii. Rev. Ch. Hist. Nat. 77, 243250.

Timothy, GE. 2009. GeneMapper ${ }^{\circledR}$ Software Version 4.1: Microsatellite Analysis Getting Started Guide, Applied Biosystems. Available at: http://www.appliedbiosystems.com

Wikondi, J, Meutchieye, F, Ayagirwe, RBB, Poutougnigni, MY and Manjeli, Y. 2015 Diversité génétique des populations des cobayes (Cavia porcellus) de la zone agro-écologique des hautes terres de l'Ouest-Cameroun, Bull. Anim. Hith. Prod. Afr. AnGR Special Edition, 343 - 352.

Wu, F, Huang, Y, Ma, Y, Hu, S, Hao, J, Li, N. 2009. Evaluation of genetic diversity and relationships within and between two breeds of duck based on microsatellite markers. Prog. Nat. Sci. 19, 15811586.

Yiva, $\mathrm{CH}$, Fon, DE, Meutchieye, F, Niba, AT, Manjeli, Y, Djikeng, A. 2014. Cavies for income generation, manure for the farm and meat for the table. Scholarly J. Agric. Sci. 4, 260-264. 